\title{
Richard Kvetnansky: His Great Contributions to Research on Catecholamines and Other Neurotransmitters in Relation to Stress
}

\author{
Toshi Nagatsu ${ }^{1,2}$
}

Published online: 3 March 2017

(c) Springer Science+Business Media New York 2017

I was deeply shocked, and a profound sense of sadness and regret enveloped me when Dr. Juan Saavedra at Georgetown University, USA, Editor-in-Chief of Cellular and Molecular Neurobiology (CEMN), a Nature-Springer journal, informed me of the passing of our long-time mutual friend Richard Kvetnansky on August 17, 2016. Prior to his death, Richard was the Director of Institute of Experimental Endocrinology, Center of Excellence of European Union, Slovak Academy of Sciences at Bratislava, Slovakia, as well as a member of the CEMN Editorial Board.

Over his long career, Richard made enormous contributions to the study of STRESS in relation to catecholamines and other neurotransmitters, especially from a neurochemical point of view.

He was very well and active when I met him for the last time in September 2012 at the tenth International Catecholamine Symposium at Asilomar, California, USA. So, it is still difficult for me to accept his departure from us.

I first established contact with him in 1973, when he sent me a letter asking me to send him a reagent for the assay of dopamine beta-hydroxylase activity, which reagent was difficult to obtain in Bratislava, Slovakia at that time. I immediately sent him the reagent, and since then we became long-time friends with common interests in catecholamines and other neurotransmitters in relation to stress.

Toshi Nagatsu

tnagatsu@fujita-hu.ac.jp; tnagatsu@riem.nagoya-u.ac.jp

1 School of Medicine, Fujita Health University, Toyoake, Aichi 470-1192, Japan

2 Department of Brain Life Science, Research Institute of Environmental Medicine, Nagoya University, Nagoya, Aichi 464-8601, Japan
Richard organized the very first International Symposium on "Catecholamines and Stress" in Bratislava in 1975, and I was invited to this symposium. Since then he organized the International Symposium on "Catecholamines and Other Neurotransmitters in Stress" every four years at Smolenice Castle near Bratislava in Slovakia: the second in 1979, the third in 1983, the fourth in 1987, the fifth in 1991, the sixth in 1995, the seventh in 1999, the eighth in 2003, the ninth in 2007, the tenth in 2011, and the eleventh in 2015. I attended, as one of the international organizers, all of those symposia except the sixth and eleventh ones. Richard organized each symposium so perfectly and attractively, with the venue also including enjoyable entertainment. The photo included herein (Fig. 1) shows the attendants of "the Tenth Symposium on Catecholamines and Other Neurotransmitters in Stress" at Smolenice Castle, Slovakia in June 2011.

Even though there are no national borders in science, during the time of the cold war in the latter part of the twentieth century, it must have been extremely difficult for Richard to organize an international symposium in Slovakia, but he always exerted enormous efforts to overcome any difficulty. All scientists from eastern countries in Europe, USA, and Japan gathered at the Vienna Airport, and Richard kindly arranged a bus to take us to Smolenice Castle in Slovakia, requiring the crossing of the national border between Austria and Bratislava. During the time of the cold war, it took 2-3 h to cross this national border.

For many years until his death, Richard was the Director of Institute of Experimental Endocrinology, Center of Excellence of European Union, Slovak Academy of Sciences, at Bratislava, Slovakia. He also worked at the National Institutes of Health (NIH) in the Laboratory of Dr. Irwin J. Kopin, USA. Thus, he had many good international friends in the USA, Europe, and Japan, who were among 


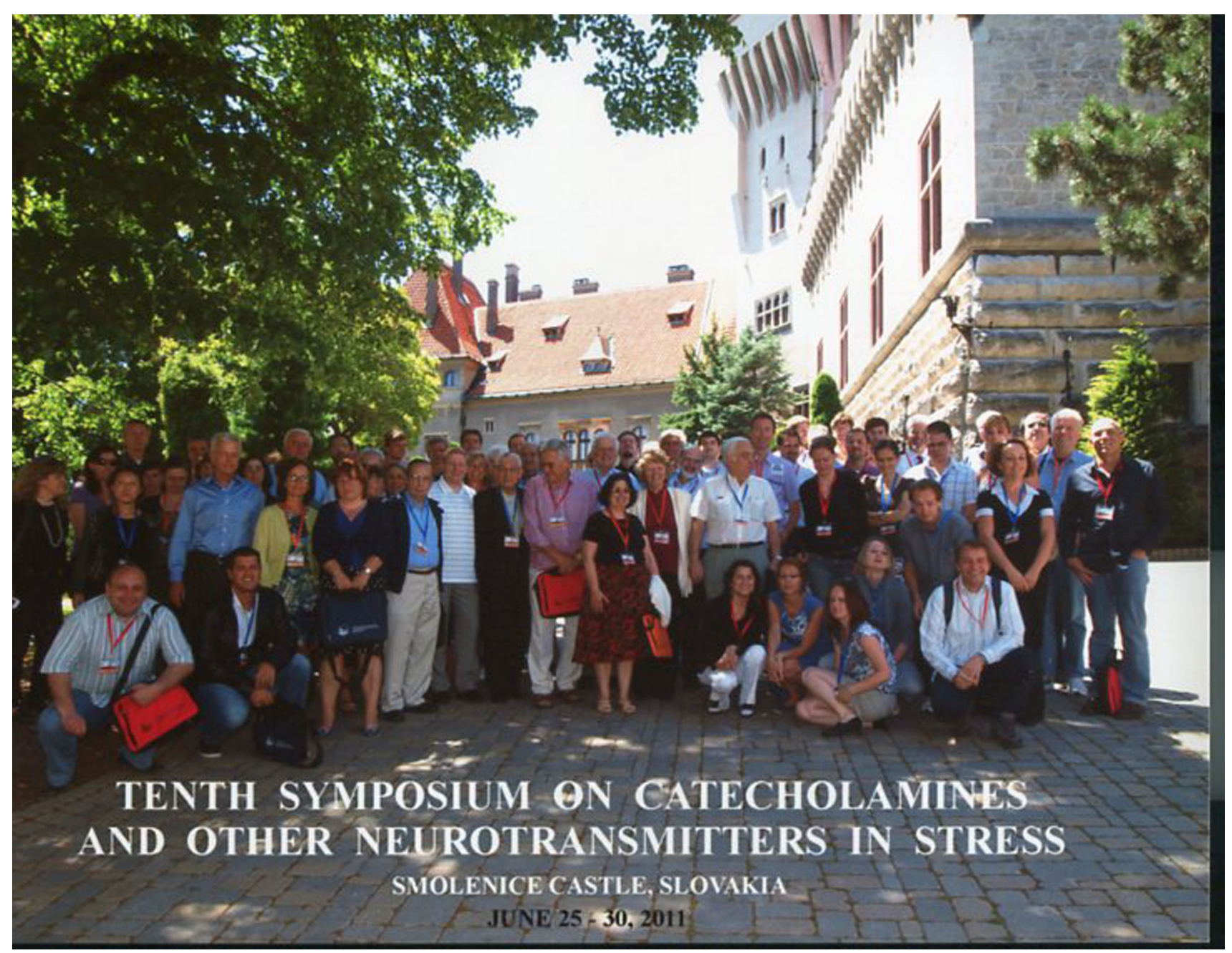

Fig. 1 Attendants at "the Tenth Symposium on Catecholamines and Other Neurotransmitters in Stress" at Smolenice Castle, Slovakia in June 2011. (Richard Kvetnansky, wearing a white shirt, is standing in the front line of the standing persons, the fourth person from the right.)

the attendants of the International Symposium on Catecholamines and other Neurotransmitters in Stress. He also carried out excellent collaborations with Dr. Esther Sabban in the USA and Dr. Miklos Parkovits in Hungary (Kvetnansky et al. 2009).

Richard visited us in Japan several times. In the late twentieth century, it was not easy to travel from Bratislava to Japan. He went first to Moscow, then took a flight to Siberia, and then a boat to Yokohama. Dr. Hiroshi Saito, Professor of the University of Tokyo, and I would always meet him at the Yokohama Port. Richard presented several excellent lectures in Japan, and he also enjoyed Japanese culture.

Richard was a very warm, kind, gentle person with strong courage. He must have had many difficulties for carrying out his science work in Slovakia, especially during the late twentieth century, but he never gave up on pursuing his research. Over his career he did excellent pioneering work on stress mainly performing neurochemical and molecular biological studies on experimental animals (Kvetnansky et al. 2009). Once I asked him why he had become interested in stress research. In reply he answered me with a bright smile, saying that he so admired Hans Selye, who had presented the concept of "stress" in physiology and medicine for the first time in the 1950s, that he wanted to elucidate the molecular mechanism of stress in health and disease.

His excellent pioneering work on catecholamines and other neurotransmitters in stress will remain forever a bright spot in the history of neuroscience, as will our memory of this man with a warm and bright personality as well as with a strong will and enthusiasm for science.

\section{Reference}

Kvetnansky R, Sabban EL, Palkovits M (2009) Catecholamine systems in stress: structural and molecular genetic approaches. Physiol Rev 89:535-606 